\title{
BIOLOGICAL OCEANOGRAPHY IN CANADA (WITH SPECIAL REFERENCE TO FEDERAL GOVERNMENT SCIENCE)
}

\author{
W. G. HARRISON \\ Ecosystem Research Division, Science Branch \\ Department of Fisheries and Oceans, Maritimes Region \\ Bedford Institute of Oceanography \\ PO Box 1006 \\ Dartmouth, Nova Scotia B2Y $4 A 2$
}

\begin{abstract}
This is a personal account of the history, accomplishments and future of biological oceanography in Canada with emphasis on Canadian government research. Canadian biological oceanographers have a rich history pre-dating the formal beginning of marine scientific research in the country with the establishment of the St Andrews and Nanaimo field stations in the early 1900s. Over the years, they have distinguished themselves by being leaders in the early developments of the discipline, including methodologies, concepts and understanding of both the pelagic and benthic ecosystems. In more recent years, Canadian biological oceanographers have led in the conceptualization, planning and implementation of major interdisciplinary/international research initiatives on climate change and ecosystem dynamics. Additionally, they are making important contributions to ecosystem and climate monitoring, research aimed at understanding the influence of ecosystems on harvestable living resource variability and on climate change, and development and application of ecosystem and climate models. Canadian biological oceanographers have made and continue to make significant contributions to the understanding of the biology of the oceans and its interactions with the physical, chemical and geological world. The challenge of solving the complex scientific and societal problems of the future will require better planning, coordination and stronger commitment to the ocean sciences by universities and government than is currently in place. Strategic planning to define goals and responsibilities is urgently needed and should include not only government and universities, but also private sector research and industry.
\end{abstract}

Ceci est une vue personnelle de l'historique, des réussites et de l'avenir de l'océanographie biologique au Canada qui metl'accent sur la recherche gouvernementale canadienne. Les océanographes biologiques canadiens ont un passé riche qui pré date le début officiel de la recherche scientifique marine dans ce pays avec la fondation des stations marines St. Andrews et Nanaimo au début des années 1900. Au fil des ans ils se sont distingués par leur rôle de chef de file dans le développement de cette discipline, couvrant les méthodes, les concepts et la compréhension des écosystèmes pélagiques et benthiques. Les océanographes biologiques canadiens ont mené dans la conceptualisation, la planification et la mise en place d'initiatives majeures en recherche multidisciplinaire et internationale sur le changement climatique et la dynamique des écosystèmes. De plus, ils font actuellement des contributions importantes à la surveillance du climat et des écosystèmes, à la recherche visant à comprendre l'influence des écosystèmes sur la variabilité des ressources marines exploitables et sur le changement climatique, et au développement et à l'application des modèles climatiques et écosystémiques. Les océanographes biologiques canadiens ont fait (et continuent à faire) des contributions significatives à notre compréhension de la 
biologie des océans et de ses interactions avec la physique, la chimie et la géologie. Les défis soulevés par les problèmes scientifiques et socio-économiques complexes de l'avenir exigent une meilleure planification et coordination et un engagement plus fort envers les sciences océaniques que démontré présentement par les universités et les gouvernements. II est urgent de développer une planification stratégique qui définit les objectifs et les responsabilités pour rencontrer les défis de l'avenir et qui inclue non seulement les gouvernements et les universités, mais aussi la recherche privée et l'industrie.

\section{INTRODUCTION}

Biological oceanography is one of the four cornerstones of the field of oceanography; the others are geological, physical and chemical oceanography. There is often confusion about exactly what constitutes biological oceanography. Marine biology, the study (physiology, behavior, etc.) of organisms of marine origin, is most often associated with the term biological oceanography. However, biological oceanography is concerned more with the interactions of marine organisms among themselves and with the physical, chemical and geological processes of their environment rather than with the study of individuals. Biological oceanography, indeed, is the multidisciplinary study of the ecology of the oceans. Parsons et al. (1984), in their popular book on this subject, indicate that the "biology" considered in biological oceanography includes not only the plankton (bacteria, phytoplankton, zooplankton, invertebrate and vertebrate larvae) of the inshore, coastal and oceanic pelagic zones, but also the benthos. They go further to suggest that fisheries oceanography could also be included in the broader definition of biological oceanography. The curriculum for biological oceanography in most well-known North American universities, for example, includes courses such as: marine microbial ecology, phytoplankton ecology and marine primary production, zooplankton ecology, marine benthic ecology, etc. One course description states: "Principles of Biological Oceanography - Lectures and discussion of the fundamental processes underlying primary and secondary production in marine ecosystems. Examples are drawn primarily from offshore systems. Emphasis on physical processes supporting primary production, plankton dynamics, biotic interactions structuring communities, vertical and horizontal distributions, foodweb structure, ecological role of higher and lower trophic levels, and benthic-pelagic coupling. The course concludes with a survey of the major oceanic ecosystems." Clearly, biological oceanography is broad in scope and interfaces with all of the major ocean disciplines. In fact, the term "biogeochemistry" (the processing, recycling, storage and transport/loss of chemical components within the marine environment, mediated by biological processes (Black \& Shimmield 2003)) is in common use and illustrates how the distinction between biological oceanography and the other major ocean disciplines is becoming less well defined.

In this short review, I will place most emphasis on the plankton because this is the biological community with which I am most familiar; it in no way 
diminishes the importance of the other biological communities of the sea. My intent is to describe briefly the origins of biological oceanography, how the discipline has developed and where it might be (or should be) going. My focus to a great extent will be on Canadian research and more specifically federal government science. I hope that the topics discussed, however, can be viewed in a broader context, applicable also to university as well as government science and with regional to global relevance.

In 1975, Professor TR Parsons (Fig 1), University

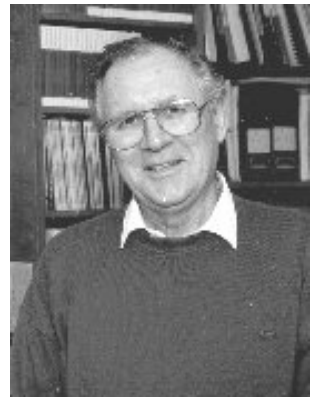

Fig 1

Professor T. R. Parsons of British Columbia (UBC), wrote a review and perspective on biological oceanography in Canada for the Fisheries Research Board of Canada (Parsons 1975). This report provided a particularly comprehensive and insightful discussion of the status of Canadian biological oceanography up to the decade of the 1970s and will serve as a reference point for my observations, comments and conclusions. How much have we advanced in our understanding of the biology of the oceans in the last $\sim 30$ years? There have also been a number of studies published in more recent years that have identified the cumulative accomplishments in biological oceanography and speculated on where the field should be headed - driven by unanswered fundamental questions and societal needs. I will highlight some of that discussion in this review.

Finally, this review largely reflects my own personal perspective (and biases); any major omissions are not intentional and simply reflect my inability to keep pace with the accelerating growth of this discipline.

\section{BEGINNINGS}

Probably the best known and most comprehensive review of the origins and chronology of the development of biological oceanography as a discipline is that of Mills (1989). Although the biological observations made during the famous Challenger Expedition, 1872-76, are thought to have marked an important step in the development of biological oceanography, research begun years earlier in European, especially German and Scandinavian laboratories, is credited with establishing biological oceanography as a quantitative science. Motivated not only by scientific curiosity, but also by a desire to understand how changes in the ocean environment might be contributing to declining regional fish stocks, scientists in the eastern North Atlantic began detailed studies of the distribution, composition and productivity of marine plankton starting in the early to mid-1800s. Notable among members of the Kiel Group were: (1) Victor Hensen who coined the term "plankton" and was among the first to propose a link between plankton production cycles and fisheries, (2) Hans Lohmann who first described the annual cycle of plankton from his studies in Kiel Bight and described 
the succession of species over the year, (3) Karl Brandt who developed early ideas about nutrient control of plankton cycles and productivity, and (4) Alexander Nathansohn and (5) H.H. Gran who proposed that ocean circulation (mixing and stratification) and light had a strong influence on the distribution, seasonal cycle and production of plankton in the ocean. A synthesis of many of these ideas and concepts was captured in Murray and Hjort's milestone textbook, "The Depths of the Ocean", published in 1912. Significant also about this time was the formation of the International Council of the Exploration of the Sea (ICES), primarily for the purpose of applying oceanographic research to fisheries problems. Johan Hjort and Harald Sverdrup were instrumental in establishing ICES as a credible instrument for fisheries research and, with its specialized research fleet, for integrating oceanographic observations with fisheries in a systematic way (Stewart 1991).

Following the advances made by the Kiel Group in developing the ideas and foundations of modern biological oceanography, scientists at the Plymouth Marine Lab in the United Kingdom (UK), through the use of refined methodology and more detailed observation in the field and lab, established indisputable evidence of the importance of nutrients, light and community interactions (grazing) on the dynamics of plankton populations. Important players in the Plymouth Group were: Atkins, Harvey and Cooper who elucidated the cycles of inorganic and organic nutrients (phosphorus and nitrogen) and their link to phytoplankton growth, Atkins and Poole who developed new instrumentation and experiments to demonstrate light limitation of phytoplankton growth and Harvey, Cooper, Lebour and Russell who described the connections between phytoplankton and zooplankton growth cycles and revealed the role grazing plays in the decline of phytoplankton blooms. With a near complete picture of the plankton foodweb in quantitative terms, Harvey reasoned that it should be feasible to describe the dynamics in mathematical terms and thus introduced modelling to the field of biological oceanography.

If Harvey and colleagues were first to explore the utility of mathematical modelling, the United States (US) group and UK colleagues, led by notable figures in the 1940s and 1950s such as Gordon Riley and John Steele, developed the tool of modelling in biological oceanography to the level of a discipline in itself. These early models provided the foundation for the sophisticated, coupled biogeochemical - circulation models in use today to help understand the global ocean carbon cycle and its role in climate change (Doney et al. 2002), and for ecosystem models used to help understand better the dynamics of plankton populations in coastal waters and the influence of ocean physics on higher trophic levels (Weibe et al. 2001). The basic questions, approaches and tools used by these early biological oceanographers are still in use.

The history of the development of biological oceanography in the western Atlantic, and Atlantic Canada specifically, has been well summarized in two reviews (Hachey 1961, Colton 1964). Probably of singular importance to 
the development of ocean sciences in Canada was Professor EE Prince's (Commissioner and General Inspector of Fisheries of Canada) efforts to establish two marine science laboratories in the early 1900s, one in St Andrews, New Brunswick, the St Andrew's Biological Station (SABS) (Fig 2) and one in Nanaimo, British Columbia, the Pacific Biological Station (PBS). At about the same time, Norwegian fisheries surveys in the NW Atlantic led by Hjort and Murray included oceanographic observations in Atlantic Canadian waters. A few years later, Hjort was commissioned by the Canadian Marine and Fisheries Department to lead a more extensive survey, the major Canadian Fisheries Expedition of 1915. Starting in the early 1900s and continuing into the 1940-50s, extensive oceanographic studies were carried out in the Gulf of Maine and adjacent waters, and included circulation/hydrography, chemistry, phytoplankton, zooplankton, benthic fauna, fisheries and geology. Prominent among the oceanographers of that time were Bigelow, Clarke, Redfield and Riley. In the 1950s and 1960s, Dunbar, Grainger and Bursa made the first biological oceanographic observations in the Eastern Canadian Arctic (Parsons 1975).

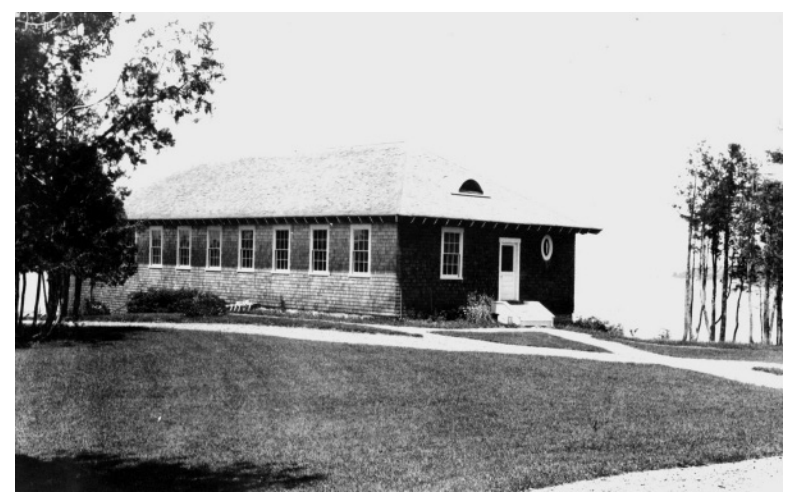

Fig 2 St Andrews Biological Station (SABS), main laboratory 1908

In 1962, the Canadian government (through the then, Department of Mines and Technical Surveys) constructed the Bedford Institute of Oceanography (BIO) in Nova Scotia, Canada's largest oceanographic institution. Over the past 4 decades, BIO has been a major centre of biological oceanographic research, most notably in studies of the distribution, physiology and production of phytoplankton and zooplankton (Clarke et al. 2003). On the west coast, a research program at PBS under the leadership of John Strickland, Tim Parsons and colleagues, was developed to understand better the link between the environment and fish and established the foundations for standard biological and chemical oceanographic measurements (Strickland \& Parsons 1972) and for contemporary tropho-dynamical studies of the plankton in the ocean (e.g. Parsons \& Lalli 1988, Harrison \& Parsons 2001). Without question, his textbook on biological oceanography (Parsons et al. 1984), 
in its third printing, remains the best known and most widely used resource for training biological oceanographers at the university level. Biological oceanographic research on the west coast has now largely moved to DFO's oceanographic facility, the Institute of Ocean Sciences (IOS) in Sidney, British Columbia. The department's laboratory, the Maurice Lamontagne Institute (MLI) in Mont-Joli, Québec, is its newest major oceanographic research centre. Oceanographic research is also done, but to a lesser degree, at DFO laboratories in Newfoundland (Northwest Atlantic Fisheries Centre, NWAFC) and New Brunswick (Gulf Fisheries Centre, GFC). At the same time that biological oceanography was gaining a foothold in government laboratories, Canadian universities were building strong departments and educating an impressive cadre of professionals, many of whom have had a significant influence on the development of the field (e.g. Louis Legendre, currently Directeur du Laboratoire d'océanographie de Villefranche-sur-Mer, France). Major university oceanographic centres are found at or associated with: the Universities of British Columbia, Victoria, Guelph, McGill University, Laval Université, Université du Québec à Rimouski, Dalhousie University and Memorial University.

\section{ACHIEVEMENTS TO DATE}

\section{The Canadian perspective}

Tim Parsons, in his review of the status of biological oceanography in Canada in the mid-1970s and its interactions with other ocean disciplines, identified strengths and weaknesses in our research programs, infrastructure and training and offered a number of recommendations (Parsons 1975). It is instructive to review those recommendations and comment on what progress has been made in the intervening 30 years and to comment on what should be the burning questions for the future.

Parsons described a number of problems in biological oceanography where knowledge of the physical properties of the ocean could provide answers. However, he characterized the interactions of researchers in the two sub-disciplines (in the mid-1970s) as minimal. Thirty years later, the situation has improved considerably. Training at the graduate level by-and-large exposes students of biological oceanography to the allied disciplines (physics, chemistry, geology, fisheries) in a more systematic and comprehensive way. Multidisciplinary research projects at the regional, national and international levels are now the rule rather than the exception. For example, the international Global Ocean Ecosystem Dynamics program (GLOBEC) (Barange \& Harris 2003, http://www.pml.ac.uk/globec/main. $\mathrm{htm})$, and the more recent Ecosystem Studies In Sub-arctic Seas (ESSAS) (http://www.pml.ac.uk/globec/structure/regional/essas/essas.htm) program in which Canada has played a leading role, address on the climate scale the variability of ecosystems driven by physical processes. Activities in ocean modelling, similarly, reflect the merger of disciplines; regional ecosystem models are now driven by sophisticated mixed-layer dynamics and global 
general circulation models commonly include biological sub-models (Doney at al. 2002, Denman 2003).

The same can be said for the current interactions of biological and chemical oceanographers compared with 30 years ago. As mentioned earlier, what might be referred to as a new discipline, biogeochemistry, has emerged from the collaboration of biological and chemical oceanographers addressing common problems related to climate change and the global elemental cyles (carbon, nitrogen, phosphorus, sulfur, etc.). A number of international research initiatives with strong Canadian participation have reflected this merger of disciplines. The Joint Global Ocean Flux Study (JGOFS) (Fasham 2003, http://www.uib.no/jgofs/jgofs.html) was a 20-nation, decade-long multidisciplinary program aimed at assessing more accurately and understanding better the processes controlling regional to global and seasonal to interannual fluxes of carbon between the atmosphere, ocean surface and interior, and their sensitivity to climate changes. A more recent international program, the Surface Ocean - Lower Atmosphere Study, (SOLAS) (IGBP 2003, http://www.uea.ac.uk/env/solas/), builds upon what was learned from JGOFS to develop a better quantitative understanding of the key biogeochemical-physical interactions and feedbacks between the ocean and the atmosphere, and how this coupled system affects and is affected by climate and environmental change. The newest international research initiative, the Integrated Marine Biogeochemistry and Ecosystem Research program (IMBER) (http://www.igbp.kva.se/obe/IMBERSP-IS-15Jan04.pdf), aims to improve the understanding of ocean biogeochemistry by considering the influence of ecosystem structure; it also has representation from the Canadian oceanographic community.

Within biological oceanography itself, interactions among specialists in different components of the plankton community (viruses, bacteria, protozoans, micro-zooplankton) have helped to elucidate, for example, the intricacies of the "microbial loop", the process by which microbial mineralizers and their grazers reprocess dissolved organic and inorganic metabolic by-products for return to the pelagic foodweb (Azam et al. 1983). Plankton specialists and benthic ecologists have worked together in a similar way to provide new insights into benthic-pelagic coupling in coastal and continental shelf waters; Canadian scientists have been in the forefront of this area of research (Hargrave 1985).

Perhaps as a result of his career-long personal interest in the role of environment and ecosystems on fish population dynamics and fisheries, Parsons paid special attention in his 1975 review to the shortcomings of fisheries science and management theory of the day to adequately consider environmental effects in explaining fish stock variability, recruitment, growth and mortality. The example was provided of the gradual failure of fisheries due to climatic effects and the emergence of new stocks and of how understanding the biological oceanography of the sea is essential for predicting such changes. It was at about this time that Cushing's "matchmismatch" hypothesis (Cushing 1972) was published and showed promise 
in explaining why the period of larval fish survival at first-feeding was critical for subsequent recruitment success of the species to the fishery. Unfortunately, the observational capabilities to test this hypothesis were inadequate then and as a consequence it remained a plausible, yet largely unproven, link between ecosystems and fisheries. Recently, the advent of satellite remote-sensing of ocean colour, which provides spatially and temporally synoptic fields of phytoplankton biomass, has permitted a re-examination of Cushing's hypothesis. Canadian biological and fisheries oceanographers have compared annual recruitment variability in haddock on the Scotian Shelf with variability in the timing of the spring phytoplankton bloom (Platt et al. 2003) and zooplankton reproduction (Head et al. 2005) and found a high correlation between strong recruitment years and early plankton growth. Further analysis (Head et al. 2005) showed that haddock larval hatch earlier than historical spawning periods during strong recruitment events and suggest that early spawning incurs survivability advantages. These are encouraging results that lend support to the match-mismatch hypothesis and open the door to research that may better establish quantitative connections between foodweb properties and fish dynamics.

Parsons proposed that biological oceanographers take a more active role in developing a better understanding of how ocean properties govern fish population dynamics. With this information, they could then generate suites of oceanographic "indices" through systematic ocean monitoring that could prove useful in explaining fish stock variability. Parsons' long interest in this approach has begun to bear fruit. In 2001, he was awarded the prestigious Japan Prize in Marine Biology for his contributions to the development of biological oceanography in general and specifically for his contribution to the concept of fisheries management based on the dynamics of fish and their oceanographic environment (Parsons 2004). In addition, growing interest within the international ocean resource management and conservation communities in ecosystem-based approaches (Turrell 2005) has highlighted the wisdom of Parsons' pursuits. Canada, and DFO in particular, is taking a leading role in the implementation of ecosystem monitoring, e.g. the Atlantic Zone Monitoring Program (Therriault et al. 1998), and in the development of a framework for ecosystem-based fisheries management (EBFM) that aims to incorporate oceanographic information into the resources assessment process (Sinclair et al. 1999, see also Halliday \& Fanning 2006).

Finally, Parsons proposed a way in which tropho-dynamics principles may be used to understand how ecosystem characteristics might facilitate the prediction of fish stock variability and cited some research supporting that view. The widespread application of static mass-balance models such as ECOPATH (http://www.ecopath.org/) and its dynamic modules ECOSIM and ECOSPACE by Canadian university scientists in the past decade (Pauly et al. 2000), for example, has offered one approach for applying biological oceanography to fisheries problems. However, in his most recent comments on the future of biological oceanography, Parsons (2002) suggested that our current understanding of trophic transfer efficiencies is poor and 
that better data, better parameterization and model integration should be priority areas of research.

At the time of Parsons' review, marine aquaculture in Canada was such a new industry that the nature and scope of oceanographic information requirements were largely speculative. He indicated, however, that water quality would certainly be an issue, requiring the expertise of biological oceanographers. In addition, advice would likely be sought on potential food sources (plankton) for cultured filter-feeding species and potentially deleterious effects from natural phenomena such as "red tides". Finally, site selection criteria might require information on ocean properties provided by biological oceanographers (e.g. productivity, trophic state, etc.). Speculation again translated to reality - the phenomenal growth of aquaculture in Canada over the past two decades has generated concern from environmentalists and resource managers about the availability, suitability and carrying capacity of coastal habitats to sustain the industry's growth. Canadian oceanographers are playing a major role in addressing all of these issues (DFO 2003, Hargrave 2005).

The growing concern about marine pollution in coastal waters and the role of biological oceanography in addressing this concern was the last environmental issue Parsons raised in his review. He believed that biological oceanographers' primary mission in pollution research is to characterize the various food webs in the marine environment, presumably including both those of healthy and impacted habitats. The international Controlled Ecosystem Pollution Experiment (CEPEX) program, conducted in Saanich Inlet, BC in the early 1970 s, was based on this whole-ecosystem (mesocosm) approach (Reeve et al. 1982), but was sustained for only a few years. The need is clearly evident today. In addition to inshore industry-based pollution, the expanding offshore oil and gas industry off Atlantic Canada raises the concern about impacted ecosystems away from the shoreline. Increasingly, biological oceanographers are asked to address the environmental impacts of such activities on the planktonic and benthic ecosystems. In Canada, and Atlantic Canada in particular, expertise and research on the subtle effects of pollution on ecosystem components or whole communities are virtually non-existent, but the problems are of growing concern. Fortunately, mesocosm research is showing some resurgence.

In addressing the overall needs in Canada for biological oceanographic expertise, Parsons commented on the instrumentation, infrastructure and facilities required to sustain a significant contribution. Exploitation of new technologies was emphasized, including in-water towed bodies with capabilities to detect and enumerate plankton (particle counters, lasers, acoustics) and measure nutrient salts and above-water aircraft/satellite-based ocean sensors. Numerous examples can be provided where Canada has led over the last two decades in the R\&D, commercialization and application of towed particle counters (Dessureault 1976, Herman 1988) and in the application and interpretation of aircraft and satellite-based remote sensing of ocean colour, as mentioned previously (Platt et al. 1995). Both activi- 
ties, however, are seriously under-funded at present; Canada continues to lose ground as an international leader in these areas of R\&D. In his most recent discussion on the future of biological oceanography, Parsons (2002) emphasized the need for integration of observations (now routinely collected using the technologies that were only on the drawing board at the time of his 1975 review) into dynamical models, i.e. biological oceanography now has the capability and must contribute to the growing field of "operational oceanography".

A clear Canadian example of progress towards that objective is the Lunenburg Bay Project in Nova Scotia (www.cmep.ca/bay). This project, entitled Interdisciplinary Marine Environmental Prediction in the Atlantic Coastal Region" involves the collaboration of university, government and private sector researchers. This multidisciplinary team is attempting to develop a real-time prediction capability for environmental phenomena in coastal embayments on the daily to weekly time scales and includes: waves, surface winds, upwelling/circulation and ecosystem response (e.g. algal bloom dynamics).

In summary, Parsons made a series of short and long-term recommendations to promote and secure biological oceanographic expertise in Canada. I have highlighted a few of these here. With regard to the short-term, he recommended that:

- Biological oceanographers should become more involved in all aspects of fisheries research.

In the context of the current interest in ecosystem-based resources management, this would seem a particularly relevant recommendation today; however, efforts in the Canadian government or academia to address this point are modest at present, but growing. Within DFO, considerable redirection of effort and resources to support the ecosystem approach is underway.

- Biological oceanographers should become more involved in pollution research.

This has had little discussion in Canadian government science circles or academia, although some relevant modelling work has been done recently (Rivkin et al. 2000, Khelifa et al. 2003). The growth of offshore oil and gas in Atlantic Canada and increased demands on DFO to provide the advice on environmental impacts makes this a relevant recommendation today; DFO currently lacks biological oceanographic expertise in this area.

- Long-term monitoring programs to measure biological parameters should be started in certain critical marine areas, e.g. The Strait of Georgia, Gulf of St. Lawrence, Grand Banks.

In 1998, DFO implemented the Atlantic Zonal Monitoring Program (AZMP) which largely addresses this point (Fig 3); The Gulf of Saint 


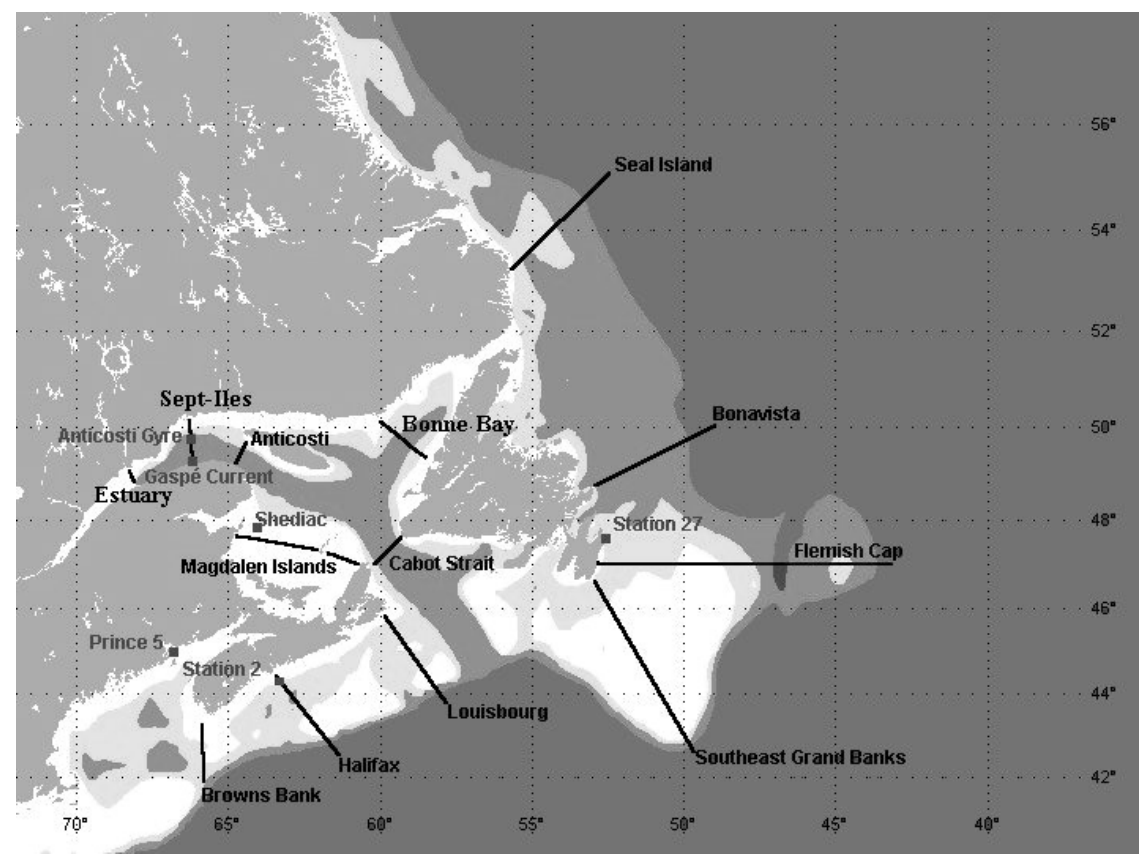

Fig 3 Sampling stations (point) and sections (line)-DFO's Atlantic Zone Monitoring Program, AZMP (Therriault et al. 1998)

Lawrence and Grand Banks are included in the more geographicallyextensive monitoring program (Therriault et al. 1998). A formalized ecosystem monitoring program in the Pacific has not yet been implemented although a number of monitoring activities, e.g. OWS "PAPA" observations, have a long history. Planning is underway for a national monitoring network across Canada, as part of DFO's Climate Change Science strategy, that will include oceanographic observations in the three oceans bounding Canada: the Atlantic, Pacific and Arctic. This will, however, require a considerable investment of new or redirected resources.

- Regional input of government funds in support of biological oceanography should be predicated on a clear demonstration of government, university and industry cooperation.

No new government funds within Canada for biological oceanography have been forthcoming. On the contrary, government scientists are being asked to continue to do more with less. Government, university and industry cooperation and resource sharing will be essential for maintaining a critical mass of biological oceanographic expertise in Canada. Biological oceanographic research within DFO has benefited greatly from partnerships and collaborations with Canadian and international 
scientists (e.g. JGOFS, GLOBEC, SOLAS programs). The partnership between university and government must be continued and enhanced; however, it should be recognized that broad biological oceanographic expertise must reside in both institutions to address their complementary roles and responsibilities. Government must continue to take the prime responsibility for "public good" research such as ecosystem and climate monitoring and for the provision of major infrastructure support for national oceanographic research, i.e. sea-going research platforms (ships), to sustain a viable oceanographic (all sub-disciplines) capacity within Canada. Considerable investment of new funds will be required to revitalize the aging DFO oceanographic fleet.

- More science is required in benthic ecology.

Canada's commitment to international conventions (e.g. on biodiversity), to the Canada Ocean's Act (where DFO has the mandate to identify and preserve representative marine habitats through the provision of Marine Protected Areas), and commitments to Ecosystem-based fisheries management (EBFM) mean that knowledge of the benthos in Canadian waters is essential. Although the application of new seabed mapping (multibeam) technology is being implemented by DFO and Natural Resources Canada (NRCan) to characterize benthic habitat in Canada's coastal waters (SEAMAP, http://seamap.bio.ns.ca/), DFO does not currently have the expertise nor has it committed the resources required to sustain a benthic ecology program.

Among Parsons' long-term recommendations were:

- Better research facilities are required for the study of benthic communities, including provision for research and monitoring deep-sea benthos off the continental slope.

The joint Canada-US North-east Pacific Time-series Undersea Networked Experiments, NEPTUNE (http://www.neptunecanada.ca), cable-linked seabed observatory is relevant here. (See also short-term recommendation above).

- Ecological information is needed on forage species (squid, small fish, euphausiids).

A similar recommendation was recently made by DFO's east coast Fisheries Oceanography Committee (FOC) to departmental senior management for consideration as an added observational requirement of the Atlantic Zonal Monitoring Program (AZMP). The lack of information on forage species also constitutes a huge gap in applying trophodynamic approaches to fisheries issues. The AZMP recommendation has not yet been acted upon. 
- Specific marine sites for biological research and aquaculture should be identified and held in trust for the development of experimental management strategies.

The provision in Canada's Oceans Act for Marine Protected Areas (MPAs) and DFO's Oceans Sector commitment to identifying and implementing MPAs in Canadian waters will go a long way toward addressing this recommendation. In addition, Canada's Centre for Marine Biodiversity (CMB) is working on the concept of "Discovery Corridors" (http://www. marinebiodiversity.ca/en/corridor.html) as a means of setting aside parcels of the ocean, free of exploitation, for research. A plan for the implementation of research and monitoring in these areas, i.e. who will do it and how will it be funded, has not yet been worked out.

- Industry should explore the development of in situ biological samplers that can be used from commercial vessels.

DFO is currently working with academia and industry to adapt a number of oceanographic instrument packages for deployment from commercial shipping vessels and ferries, principally to support its ocean monitoring activities. Investment in technology is viewed as a means for increasing efficiency (i.e. by reducing reliance on conventional ship-based observations) and "operationalizing" oceanographic observations. As mentioned previously, however, DFO's resource commitments for technology are relatively modest and considerably reduced from levels of a decade ago.

- More biological oceanographic work in the arctic is needed (with supporting physical/chemical oceanography).

Considering the vastness of the Canadian arctic and its importance in the global climate context among other issues, the commitment for arctic biological oceanographic research is modest at best. Canada, however, has taken a leading role in past as well as in new arctic research programs. For example, the international North Water Polynya Study (NOW) (Deming et al. 2002, http://www.fsg.ulaval.ca/giroq/now/wel. $\mathrm{htm}$ ) brought together oceanographers from countries bounding the Arctic Ocean to improve understanding of the significance of polynyas as early indicators of the effects of climate warming at the poles. More recently, the Canadian-led international research network called Canadian Arctic Shelf Exchange Study (CASES) (http://www.cases. quebec-ocean.ulaval.ca/index.html), is investigating how the atmospheric, oceanic and hydrologic forcing of sea ice variability dictates the nature and magnitude of biogeochemical carbon fluxes on the edge of the Mackenzie Shelf. Canadian government and university biological oceanographers are playing an important role in both of these initiatives. In addition, the Canadian university sector has established a national centre of excellence for arctic research at Laval University, emphasizing climate impacts on the coastal Canadian Arctic (ArcticNet, http://www. 
arcticnet-ulaval.ca), that will provide opportunities for collaboration with DFO science. Expanding research and monitoring in the north to address climate change issues have been identified as priorities in Canada, and commitments have already been made for partiicpation in The International Polar Year, 2007-2008 (IPY, http://www.ipy-api.ca).

- Better research facilities (including ships) are required in support of arctic research.

Canada (and DFO in particular) as far as I am aware does not have plans for major infrastructure development aimed at enhancing oceanographic research in the arctic. However, a dedicated research vessel, the $98 \mathrm{~m}$ icebreaker CCGS Amundsen (http://www.amundsen.quebecocean.ulaval.ca), has been jointly funded by government and academia expressly for supporting Canadian arctic oceanographic research over the next decade.

One area in which biological (as well as physical and chemical) oceanography in Canada plays a significant role not explicitly covered in Parsons' review, is climate science. Science planning within DFO has not identified ocean climate research as an area for major investments in the next decade; it has been viewed as a national, but not necessarily a departmental high priority area. This I view as a strategic error since climate change will in all likelihood be the single-most significant societal issue in the coming decades (see previous section). It will undoubtedly have significant effects either directly or indirectly on the issues of sustainable development, resource management, habitat and biodiversity - all of which DFO identifies as top priority areas of interest. It may be viewed in some quarters that, within the government, other natural resources departments (e.g. Environment Canada (EC)) should (and can) provide the science required to understand the role of the oceans in climate change; this is view with which I strongly disagree.

\section{The international perspective}

Mills' review of the early history of biological oceanography (Mills 1989), including work up to the decade of the 1960s, concluded with the observation that the science in its formative years was driven largely by politics and economics (i.e. food from the sea). Later (post-World War II), national defense interests became prominent and the navies of the developed world began to invest significantly in oceanography (of which biological oceanography initially was a small component). This was matched and surpassed, starting in the 1970s, with what is referred to as "Big Science", i.e. multi-disciplinary ocean research projects of national or often international scope. Projects under the auspices of the International Decade of Ocean Exploration (IDOE) are a good example. In biological oceanography, as is the case with other ocean disciplines, this model has continued into the 21 st century as the scientific questions being addressed have grown 
in scope (e.g. climate change). Although it is true that individual or small team biological oceanographic inquiry is still thriving, many of the contemporary achievements considered of major significance have come about through the cooperative research of scientists working in large networks on broad-scale projects.

In the last few years, the Ocean Studies Board of the US National Science Foundation (NSF) commissioned a study of the landmark achievements in oceanography over the past 50 years. Professor Richard Barber, heading up the study on biological oceanography, summarized the discussions from the retreat sponsored to address this question and responses from some 150 practicing biological oceanographers (Barber \& Hilting 2000). Barber indicates that prior to World War II (WWII), biological oceanography had two main themes: (1) locating and understanding causes of the variability in exploitable living marine resources (i.e. fisheries) and (2) curiosity-driven discovery, i.e. the search for strange and exotic organisms in the ocean. After WW II, biological oceanography became a growth industry with the infusion of significant new funds and substantial increases in universities teaching biological oceanography and the subsequent expanded pool of biological oceanography graduates entering the workforce. The balance between applied and basic research began to shift towards the latter and although effort continued in the areas of food from the ocean and new concerns about pollution, much more research was directed to discovery and knowledge for knowledge sake. Interestingly enough, the pre-war interest in collaboration between fisheries and ocean sciences lost much of its momentum in the new era, and progress in understanding the role of environment in fluctuations in living marine resource variability, recruitment and survival has progressed little in the intervening years.

Eight landmark achievements were identified in the NSF study. Four were related to new technologies for studying the ocean from within and from above. The first two were largely a consequence of the introduction of deep-sea submersibles, i.e. the discovery of much higher biological diversity in the deep-sea than had been believed up to that time and the discovery of previously unknown complex and unique chemosynthetic ecosystems residing in and around hydrothermal vents at sites of seafloor spreading. The 3rd was the remarkable research using innovative high-speed microcinematography aimed at understanding the intricate swimming, feeding and reproductive behavior of marine zooplankton. The 4th was the advent of earth resource-mapping sensors aboard orbiting satellites, namely the Coastal Zone Color Scanner (CZCS) launched in 1978 to map coastal resources. CZCS operated for almost 8 years and provided an unprecedented view of the scales of variability of ocean biota (phytoplankton chlorophyll). More precisely, CZCS provided insights into the realization of how inadequate conventional sea-going sampling (i.e. via ships) is for characterizing ocean variability and how mesoscale processes dominate the spatial patterns of distribution. Moreover, satellite ocean colour has 
revealed clearly the complexity of seasonal phytoplankton cycles and the magnitude of interannual variability, properties that have been difficult to describe adequately heretofore. Canadian oceanographers are currently world leaders (and educators) in the R\&D and application of satellite remote-sensing of ocean colour.

$A 5^{\text {th }}$ achievement, related somewhat to the advent of "satellite oceanography", but predating it, has been the application of isotopic tracer methodology $\left({ }^{14} \mathrm{C} \&{ }^{15} \mathrm{~N}\right)$ in the 1950 s and 1960 s to the study of ocean primary production. The accumulation of productivity data world-wide over the past 50 years combined with spatially synoptic ocean colour primary-producer biomass fields have permitted realistic estimates of global marine primary production for the first time (Longhurst et al. 1995). Canadian biological oceanographers, Alan Longhurst and Trevor Platt, have extended these new observations to produce a scheme for partitioning the ocean into biogeochemical domains and provinces (Fig 4) based on phytoplankton growth dynamics and the underlying physical forcings (Longhurst 2001). In a similar way, isotope tracer studies of productivity based on the nitrogen nutrition of phytoplankton from the laboratories of Dugdale and Eppley formed the basis of the $6^{\text {th }}$ achievement, a new conceptual framework differentiating "new" (or physically-mediated) from "regenerated" (or biologically-mediated) primary production (Dugdale \& Goering 1967, Eppley 1981). The new and regenerated production model has provided an explanation for regional differences in primary production and the underlying physical-biological driving forces. In addition, it has provided a rationale for relating surface production to export of biogenic matter to the deep ocean (Eppley \& Peterson 1979); a process that is critical for understanding the "biological carbon pump" and the role ocean biota play in the global carbon cycle and ultimately in climate

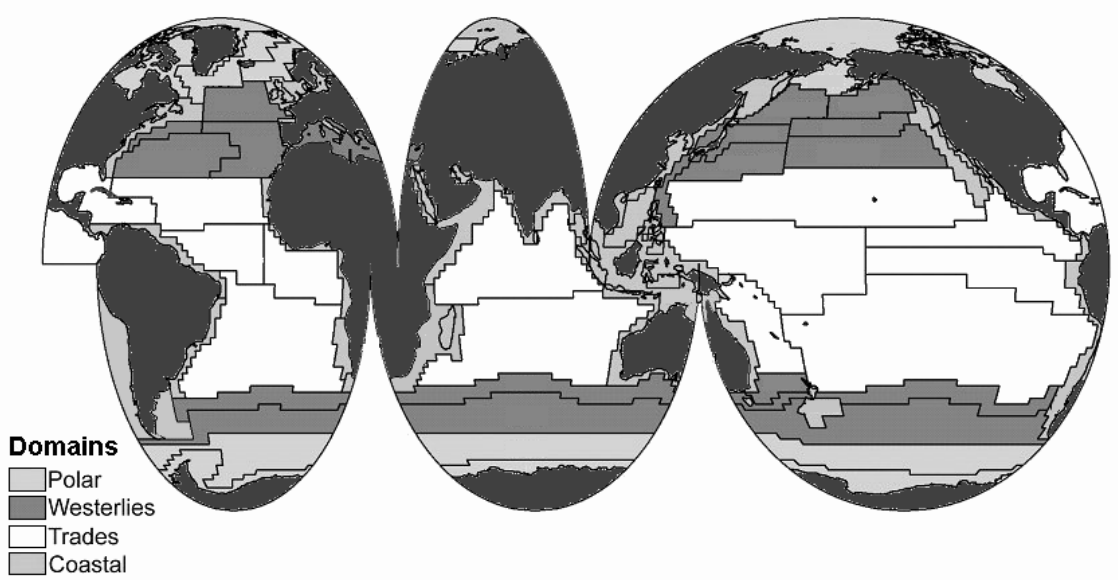

Fig 4 Biogeochemical domains and provinces of the global oceans (Longhurst 2001) 
change. Canadian university and government biological oceanographers have been strong proponents of the new and regenerated production concept and have been actively involved in its application.

$\mathrm{A} 7^{\text {th }}$ achievement was John Martin's elucidation of the "iron hypothesis" to explain the perplexing observation of vast areas of the contemporary oceans where surface nutrients are not effectively utilized by phytoplankton (Martin et al. 1994). Martin suggested that phytoplankton production is limited by the availability of atmospheric iron, an essential growth element, which is deficient in areas where surface nutrients are under-utilized. Similarly, he explained the large glacial-interglacial changes in atmospheric carbon dioxide in the geological record by the influence of iron availability on ancient productivity rates that, in turn, regulated atmospheric carbon dioxide concentrations. The Canadian biological oceanographic community has played a significant role in testing this hypothesis, through the Canadian JGOFS and more recent SOLAS programs' in situ Fe-fertilization experiments and ecosystem modelling (Boyd \& Harrison 1999).

The $8^{\text {th }}$ and last achievement, considered by the community of contributors to be the most far-reaching, is the characterization and recognition of the importance of the microbial components (viruses, bacteria, pico and nanophytoplankton, micro-grazers) of the pelagic food web. The evolving picture of a complex community of interacting microorganisms that play a pivotal role in trophic energy transfer and ocean biogeochemistry has forced the biological oceanographic community to re-examine its traditional and simplistic view (phytoplankton-zooplankton-fish) of the structure and function of the ocean pelagic ecosystem. Canadian biological oceanographers played a pioneering role in the discovery of pico-phytoplankton ( Li et al. 1983) and in establishing their role in productivity of the pelagic ecosystem; moreover, they are promoting the new concept of microbial "macro-ecology" (Parsons 2003 ) in explaining regional to global patterns in plankton distributions ( $\mathrm{Li}$ 2002, Li et al. 2004) and microbial metabolism (Rivkin \& Legendre 2001) in the ocean. Fig 5, for example, shows that the relationship between bacteria and phytoplankton at the global ocean scale is more complex than initially thought. The commonly held view of a positive bacteria-phytoplankton relationship (strong trophic coupling) holds for much of the phytoplankton concentration range. Under conditions where phytoplankton biomass is moderate to low (e.g. low latitude, continental shelf and open ocean waters), bacteria are regulated by substrate provided principally by primary productivity, i.e. "bottom-up" control processes dominate. Where phytoplankton concentrations are moderate to high (e.g. coastal, inshore, upwelling or high latitude waters), however, the bacteria-phytoplankton relationship plateaus or is negative, suggesting a fundamental trophic decoupling. Under these conditions, bacteria are more commonly regulated by bacterivory or viral attack i.e. "top-down" control processes dominate (Li et al. 2004).

Thus ocean macroecology is a means of studying the relationships between marine organisms and their environment at the largest scale (ocean basin to global) based on statistical characterization of emerging patterns 


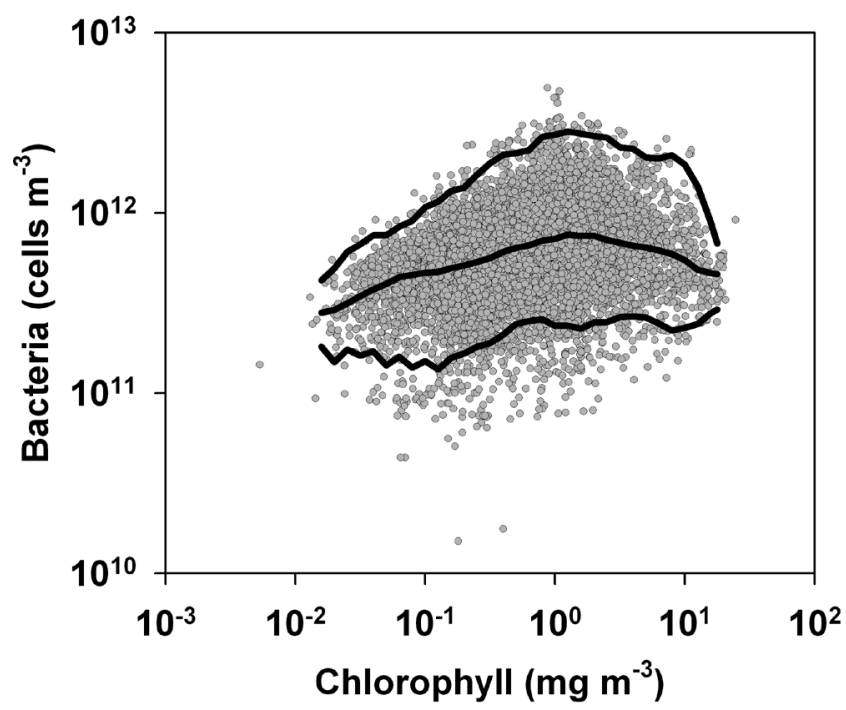

Fig 5 Macroecological analysis of the relationship between bacterial abundance and chlorophyll concentration (proxy of phytoplankton). Canadian and international JGOFS data archives from the subtropical and North Atlantic, equatorial and North Pacific, Arabian Sea, Arctic and Antarctic oceans. Statistical percentile lines are generated from bacterial distributions within successive binned ( 0.1 logarithmic units) chlorophyll intervals: the 50 percentile line (middle line), for example, defines the median bacterial abundance for a specified chlorophyll concentration; 5 (lower line) and 99 (upper line) percentiles essentially set the statistical bounds of the bacteria-chlorophyll relationship ( $\mathrm{Li}$ et al. 2004). Note the positive bacteria-chlorophyll relation at chlorophyll concentrations $<10^{0} \mathrm{mg} \mathrm{m}^{-3}$, suggesting strong trophic coupling and "bottom-up" control. At chlorophyll concentrations $>10^{0} \mathrm{mg} \mathrm{m}^{-3}$ the relationship is decoupled and bacteria are "top-down" controlled by bacterivory or viruses.

of abundance, distribution, community structure, etc. It can be considered an extension of comparative ecosystem analysis. This line of investigation in biological oceanography has benefited greatly from the proliferation of electronic databases of ocean observations, such as those that reside in the Canadian federal government's Marine Environmental Data Service (MEDS, http://www.meds-sdmm.dfo-mpo.gc.ca/meds/Home_e.htm) or other international data repositories (e.g. BODC, http://www.bodc.ac.uk/ and NODC, http://www.nodc.noaa.gov/).

\section{THE FUTURE}

\section{Societal needs}

Because of the ever-increasing cost and demands on public and private funding supporting oceanographic research, it is becoming a commonplace that a rationalization beyond mere curiosity is required. More often than not, 
justification at the highest level may be sought and based on more practical public good concepts such as maintaining a national leadership role in technology development, "wealth creation", etc. This is becoming particularly true for the support of federal oceanographic laboratories (Canada being no exception) and in the justification for international research initiatives.

Again, the Ocean Sciences Board of the US National Science Foundation (NSF), reporting on their vision of oceanography in the next decade, attempted to identify the major societal issues that will drive ocean science in the early 21st century. At the international level, the Partnership for Observation of the Global Oceans (POGO) recently produced a report on the requirements for biological oceanographic observations of the global ocean and how to meet them (http://ocean-partners.org/documents/Dartington_Report.pdf). In that report, a list of societal needs was generated that was similar to the list produced by the NSF Ocean Sciences Board. Among the most pressing issues identified were: (1) sustainable development (and management) of living marine resources and the allied issues of (2) conservation and maintenance of biodiversity and (3) habitat protection; (4) environmental quality, (5) bio-invasions, and finally (6) global (climate) change. The oceans are the largest "global commons" and Canada, as one of the "G-8" and a major maritime nation, must contribute to the stewardship of global marine resources. Furthermore, DFO has a leading role in ocean research to meet this obligation for the public good.

Each of these issues to some degree is of relevance to and should be of concern to Canadians. Government and university biological oceanographers have an important role to play in monitoring the marine environment and its resources, detecting (and predicting) change and providing advice (technical options) for managers and policy makers. Specifically, Canadian government science (DFO) has the prime responsibility for ocean resources management, conservation and habitat protection. The Canada Oceans Act, and the responsibilities it confers for the stewardship of the oceans off Canada, and DFO's commitment to an 'ecosystem approach' to resource management means that the need for biological oceanographic expertise has never been greater.

\section{Scientific problems $20^{\text {th }}$ and early $21^{\text {st }}$ century science has not yet solved}

Strategic planning on future needs for ocean sciences has been the subject of a number of discussion papers internationally in recent years. Similar scoping meetings among government and university ocean scientists encompassing the needs of Canadians in the broadest sense have not occurred yet. DFO has begun discussions on the scientific expertise it will need in the coming years, but to date the scope of these deliberations has been restricted to a relatively narrow mandate as perceived by senior managers. For the purposes of this review, therefore, I will draw on the unanswered questions posed by the international community as a guide to what Canada's future for biological oceanographic research might look 
like. Two discussion papers of particular interest are my principal sources; the Ocean Ecology: Understanding and Visions for Research (OEUVRE) workshop report sponsored by the Ocean Sciences Board of the US National Science Foundation (http://www.ofps.ucar.edu/joss_psg/project/oce_workshop/oeuvre/report/Entire.pdf) and the International Geosphere-Biosphere Program / Scientific Committee on Oceanic Research (IGBP/SCOR) joint report on future research requirements in ocean biogeochemistry (http:// www.igbp.kva.se/obe/FW-Final-2002.pdf). The latter report addresses principally issues concerned with climate change research while the former is much broader and embraces the more complete suite of societal issues posed previously.

The premise for the OEUVRE report on the future of biological oceanography is that "Humans have fundamentally affected marine ecosystems worldwide via fisheries, aquaculture, introductions of non-native species, modification or destruction of crucial habitats, and the additions of nutrients and chemical pollutants. No part of the ocean remains unaffected. Human population increases are affecting coastal oceans more profoundly and more rapidly than global climate change, producing an urgent need to understand, predict and mitigate these changes. Ocean ecology can no longer be understood adequately without recognizing these ecosystem-wide perturbations." The report goes on to indicate that the "grand challenge" is to act with incomplete knowledge and build our understanding through learning by doing. Among the greatest challenges ahead will be separating the "signal from the noise", i.e. understanding and differentiating anthropogenic effects from natural variability. Critical issues and opportunities raised in the report include:

- Ocean ecologists (biological oceanographers) must promote better stewardship of marine ecosystems by understanding and predicting perturbations and food-web alterations and by providing mitigative options.

- To meet these challenges, better understanding of causes and consequences of ecosystem change on small to large scales will be required. Sorting out these changes will, among other things, require extensive time-series of ocean observations, exploiting traditional as well as new observational technologies (molecular probes through to global scale remote-sensing).

- Prediction will require better understanding of the basic rules of ecology affecting community structure and function. Mitigation will require the application of this understanding by manipulation in some way of critical components of ecosystems (species, their interactions) that can be used to return the ecosystem to the desired state.

- Marine reserves (or Marine Protected Areas) will become valued tools in the coming decades for ecosystem preservation, recovery and for intentional manipulation for development of more effective ecosystem management strategies. 
- Understanding gained from the above can then be applied to forecast ecosystem change resulting from natural and anthropogenic effects, and assess the extent to which mitigative (restorative) actions are possible and offer options.

The nature and complexity of these important questions imply that a substantial (perhaps unprecedented) commitment of planning and resources (human and otherwise) will be required if they are to be addressed. They also imply the need for strong collaboration between university and government scientists (national and international). Biological oceanographers within Canadian universities and federal government departments (specifically DFO) are up to the challenge and have demonstrated through participation in major national and international research initiatives the capabilities needed for tackling complex scientific problems through cooperation and resource sharing (e.g. Canada's participation in JGOFS, GLOBEC, NOW, SOLAS, CASES and leadership role in new international initiatives such as IMBER). Participation of both sectors will be required since the issues include not only the science (responsibility of both academia and government) but the mitigative options that have traditionally been the purview of government.

My personal concern is that the contribution of government to the science and maintenance of its expertise in the oceanographic disciplines is increasingly being viewed as a responsibility of academia. Most academic research, however, generally has a relatively short life cycle of a few years, e.g. the SOLAS project. Societal issues of concern, on the other hand, require a much longer period of sustained study, which is better suited to government science. Compromising science capacity in the government in light of the legal responsibilities and challenges for ecosystem understanding embodied in Canada's Ocean's Act and climate issues articulated in the Intergovernmental Panel on Climate Change (IPCC) documents and Kyoto Protocols (http://www.ipcc.ch, http://unfccc.int/resource/docs/convkp/kpeng. pdf) seems short-sighted. More than ever, decisions within the government based on good science, backed up by a cadre of world-class government scientists (including biological oceanographers), will be essential. Canada, among all the developed nations, has been notable in the global science community in its strong representation by government scientists - this tradition has worked well in the past for Canada and should be continued.

The IGBP/SCOR report, addressing the way ahead for ocean biogeochemistry (and the framework for the new IMBER project), is structured around three major issues: (1) what controls the time-varying biogeochemical state of the ocean and how will it respond to global change? (2) how will the marine food webs respond to, and force, global change? and (3) how does carbon accumulation in the ocean, as well as the release of carbon dioxide and methane, respond to global change? Among these issues, a number of subsidiary questions are of particular relevance to future research in biological oceanography: 


\section{Issue 1:}

- What role will the mesopelagic layer (100-1,000 m depths) play in global change?

\section{Issue 2:}

- What are the relations between elemental cycling and food web structure?

- What are the roles of physical and chemical drivers in determining marine food web structures and functioning?

- What are the relations among biodiversity, structure, function, and stability of marine ecosystems?

- How do variations in marine food webs manifest themselves over various time and space scales?

\section{Issue 3:}

- What is the effect of climate variability on the ocean's biological pump (i.e. carbon sequestration in the deep ocean mediated by ocean biota)?

Without exception, the questions posed above are of relevance to Canada. Moreover, as mentioned previously, Canadian ocean scientists (academia and government) have taken leading roles internationally in planning and executing research on the biogeochemistry of the oceans, particularly with regard to climate change issues, and continue to contribute to the identification of the pressing problems for the future. Sustaining this momentum within Canada is clearly in the best interests of the country since climate change will be a reality for Canada; because of its geography, climate change manifestations may be more dramatic and may reach our shores well before it reaches those of our global neighbours.

In concluding the discussion of future needs in biological oceanography, I must comment on radically new technological advances in genomics (the science of mapping the genetic code of organisms and research on the implications of this molecular-level knowledge), not envisioned when Parsons wrote his review in the mid-1970s. An explosive growth of research on mapping the genetic code of marine plankton is underway. Recently, it was announced that the genetic blueprints for four closely related microorganisms in the ocean plankton (three strains of the unicellular cyanobacteria Prochlorococcus and Synechococcus) have been sequenced (Fuhrman 2003). These organisms are ubiquitous and constitute the smallest in individual size, but are the most abundant photosynthetic microorganisms in the world's oceans. In fact, contemporary communities of bacteria and protists are believed to account for up to $98 \%$ of the ocean's living biomass and have a much greater influence on the global biogeochemical cycles of the oceans than previously thought. It is anticipated that breaking the genetic code of these micro-organisms will lead to new understanding, not otherwise possible, at the organism level (e.g. photosynthetic physiology), 
community level (biodiversity) and up to the global scale where genetic research may provide new insights into the role of phytoplankton and bacteria in the ocean carbon cycle and climate change. Indeed, a new sub-discipline of biological oceanography, termed "Microbial Oceanography", has emerged as an umbrella for these new and traditional microbial studies. Efforts are well under way, for example, under the auspices of the Census for Marine Life initiative (COML, http://www.coreocean.org/Dev2Go. web?Anchor=coml_home_page\&rnd=15141) to develop a roadmap (scope, knowledge gaps, methodologies, coordination and education) for future research in this new field. Currently, there are more than 1,000 genomesequencing projects around the world. These include work on marine phytoplankton (diatoms, dinoflagellates, coccolithophores, cryptomonads, prasinophytes, prymnesiophytes), on marine bacterioplankton (cyanobacteria, proteobacteria), on marine zooplankton (appendicularian), and even on marine meroplankton species (lobster, crab, shrimp). As far as I am aware, Canadian government oceanographers are not involved in any of these projects. In modern medical research, molecular biology is already the common foundation across all sub-disciplines. There are some that draw an analogy between the health of human beings and the health of marine ecosystems; clearly, molecular biology will be an important part of the foundation of biological oceanography in the future.

An interesting fall-out from this new genetics research, as well as research into the influence of plankton community structure on ocean biogeochemistry (IMBER), is a resurgence of interest in taxonomy and systematics; disciplines that were synonymous with biological oceanography in its infancy. Experts in phenotypic classification of plankton communities are a dying breed within Canada as well as globally despite the growing need for this expertise. The problem is confounded by the fact that universities (with few exceptions) do not train oceanography students in taxonomy. More importantly, the population of scientists with even a basic knowledge of systematics is rapidly disappearing. This must be rectified. The new discipline of chemical taxonomy (including genetics) still needs the benchmark of simple microscopic analysis!

\section{CONCLUDING REMARKS WHERE DO WE STAND AND WHERE DO WE GO?}

Canadian biological oceanography has a rich history pre-dating the formal beginning of marine scientific research in the country with the establishment of the St Andrews and Nanaimo field stations in the early 1900s. Canadian biological oceanographers over the years have distinguished themselves by being leaders in the early developments of the discipline, including methodologies, concepts and understanding of both pelagic and benthic ecosystems. In more recent years, Canadian biological oceanographers have led in the conceptualization, planning and implementation of major 
interdisciplinary/international research initiatives on climate change and ecosystem dynamics and are making important contributions to research aimed at understanding the influence of ecosystems on harvestable living resource variability and conservation. Clearly, Canadian biological oceanographers have made (and continue to make) significant contributions to the understanding of the biology of the oceans and its interactions with the physical, chemical and geological world.

Present strengths in biological oceanographic research in the Canadian government fall under three broad categories: ecosystem and climate monitoring, ecosystem and climate process studies, and modelling. With regard to monitoring, the Atlantic Zone Monitoring Program (AZMP) was established by DFO principally to provide more comprehensive and systematic long-term observations of the oceanographic and foodweb properties of the NW Atlantic in support of resource management and to improve understanding of the relationships between harvestable resources and their environment - much as Tim Parsons envisaged. AZMP and other DFO monitoring activities (e.g. ecosystem trawl surveys) have proven to be of much broader significance and are playing a important role in the development, internationally, of a global network of ecosystem observations through the Global Ocean Observing System (GOOS), for example (http://ioc.unesco.org/goos/). In a like manner, climate system monitoring, (e.g. biogenic carbon inventories and transport) in the Labrador Sea in the Atlantic and OWS "PAPA" in the Pacific are making valuable contributions to the international research community seeking an understanding of the effects of climate change on ocean biota and biotic feedbacks through the ocean carbon cycle. It is also noteworthy that DFO biological oceanographers are among the world leaders in the development and application of satellite (ocean colour) remote sensing for monitoring and research. With regard to process studies, DFO biological oceanographers distinguish themselves in areas of distribution, production, physiology and trophic interactions among the plankton and microbial components of the foodweb as they relate both to ecosystem structure/function and to climate feedbacks. DFO biological oceanographers also have particular strengths in ecosystem model development and application. Noteworthy among these, for example, are inverse models (Vézina et al. 2004), data assimilation, "adaptive" optimization approaches for modelling biogeochemical interactions (Pahlow \& Vezina 2003) and parameterization of ecosystem models for integration into global climate models (Denman 2003). Sustaining Canada's strengths in biological oceanographic research, especially within federal government laboratories, will be a considerable challenge, however, if trends of shrinking resources and low recruitment persist.

Despite these strengths, there are areas in which DFO's biological oceanographic community (and oceanographers of other disciplines as well) should place more emphasis. While systematic, comprehensive, and high-quality ecosystem data collection, cataloguing and basic reporting is a major focus 
of effort in the Department at present, data integration and interpretation are lagging (see Parsons 2002). DFO also leads in the exploitation of new technologies (e.g. satellite remote sensing), however, the integration of these data with conventional observations and assimilation into dynamical models needs more effort, i.e. biological oceanography needs to move towards an "operational oceanography" mode (Parsons 2002). Finally, serious consideration needs to be given to the role DFO wants to play in the emergent field of "microbial oceanography" and genomics applications in biological oceanography. At present, DFO has limited capacity and little potential for growth in this area without significant investment. This is a true revolution in science and the time is at hand to decide if Canadian government oceanographers are going to be players or sit on the sidelines. It would be a shame indeed if DFO oceanographers were relegated to a role of handmaidens to foreign researchers who sail into Canadian waters seeking only jurisdictional assistance for their marine genome projects. The challenge of sequencing the human genome has been met and attention is now being turned to sequencing the metagenome of plankton in the ocean (Venter et al. 2004).

The challenge of solving the complex scientific and societal problems facing us now and in the future, however, will require better planning, coordination and stronger commitment to the ocean sciences by both universities and government. The government science departments, in particular, are losing critical expertise, infrastructure and capacity when the need is greatest. Without a substantial reinvestment in people, core funding and ships, the federal government's biological oceanographic research capacity (and oceanographic capacity in general) cannot be sustained. As a consequence, the department's prestige and credibility will be diminished, opportunities for collaboration and synergy will decrease and, most importantly, the department's capability to solve many of the ecological problems within its mandate will be compromised. A strong national voice for oceanography and serious strategic planning for the future to define goals and responsibilities is urgently needed and should include not only government and universities, but also industry and the private sector.

On the occasion of the $40^{\text {th }}$ anniversary of DFO's Bedford Institute of Oceanography in 2002 (Geddes et al. 2003), a number of scientific leaders in the physical, chemical, geological and biological disciplines of oceanography were invited to participate in the celebration and provide their views on the progress that has been made in their respective field over the past several decades and to speculate on its future. Professor Paul Falkowski of Rutgers University gave a compelling yet provocative talk on the past and future of biological oceanography, entitled, "Putting the Biology back into Biological Oceanography". Rather than providing a detailed history of accomplishments in the field, his presentation highlighted some of the remarkable biological oceanographic discoveries made in very recent years and showed their relevance to the understanding of some of the most fun- 
damental questions in science, such as the evolution of life on earth and the role of ocean biology in the planetary cycles of the major biogeochemical elements. He suggested, however, that biological oceanography is "on the cusp of either becoming irrelevant or making a major contribution to understanding planetary processes". He then explained his reasoning by emphasizing how much biological oceanography has to offer the other traditional ocean disciplines (physics, chemistry and geology) and the new disciplines of molecular biology and genomics and stressed the need for integration of disciplines to tackle the big questions, a number of which I described previously. Biological oceanography, in his words, is in search of context.

I am certain that Canadian biological oceanographers have a sense of their context and are now and will continue to forge alliances with physical, chemical and geological oceanographers (and new disciplines) to tackle the pressing scientific and societal problems, some of which have been highlighted above. In reality, the role Canada's oceanographers play as participants with the global science community in meeting these ambitious goals is what is presently "on the cusp". What will be required is a renewed commitment to and recognition that strong national support for oceanography is in Canada's best interest, is a good investment and is both a government and university responsibility.

Acknowledgements. The author wishes to thank Bill Li, Brian Petrie, Mike Sinclair, Peter Smith, Alain Vezina and two anonymous reviewers for constructive comments. I also wish to thank the Editor of the NSIS Proceedings, Jim Stewart, for numerous stimulating discussions that provided the impetus for writing this review.

\section{REFERENCES}

Azam F, Fenchel T, Field JG, Gray JS, Meyer-Reil LA, Thingstad F (1983) The ecological role of water-column microbes in the sea. Mar Ecol Prog Ser 10:257263

Barange M, Harris R (2003) Marine ecosystems and global change. Global Ocean Ecosystem Dynamics (GLOBEC). IGBP Science No 5, Stockholm

Barber RT, Hilting AK (2000) Achievements in biological oceanography. In: Barber RT (ed) Fifty years of ocean discovery. National Academy Press, Washington DC, $p$ 11-21

Black KD, Shimmield GB (2003) Biogeochemistry of marine systems. Blackwell Science Ltd, Boca Raton, FI

Boyd PW, Harrison PJ (1999) Canadian JGOFS in the NE Pacific. Deep-Sea Res II 46:2345-3029

Clarke A, Lazier J, Petrie B, Platt T, Smith P, Elliot J (2003) Ocean Sciences - Looking back at 40 years. In: Geddes D, Armsworthy S, Dennis P, St-Laurent B (eds) Bedford Institute of Oceanography 2002 in review. $40^{\text {th }}$ anniversary edition. DFO \& NRCan, Dartmouth, p 24-27 
Colton JB Jr (1964) History of oceanography in the offshore waters of the Gulf of Maine. US Fish \& Wildlife Service Special Sci Rep - Fish No 496

Cushing DH (1972) The production cycle and the numbers of marine fish. Symp Zool Soc Lond 29:213-232

Deming J, Fortier L, Fukichi M (2002) The International North Water Polynya Study (NOW). Deep-Sea Res 49:4487-5295

Denman KL (2003) Modelling planktonic ecosystems: parameterizing complexity. Prog Oceanogr 57:429-452

Dessureault J-G (1976) 'Batfish': a depth controllable towed body for collecting oceanographic data. Ocean Eng 3:99-111

DFO (Department of Fisheries and Oceans) (2003) Salmon holding capacity in southwestern New Brunswick. Can Tech Rep Fish Aquat Sci 2489

Doney S, Sarmiento J, Falkowski P (2002) The US JGOFS synthesis and modelling project: phase 1. Deep-Sea Res 49: 1-565

Dugdale RC, Goering JJ (1967) Uptake of new and regenerated forms of nitrogen in primary productivity. Limnol Oceanogr 12:196-206

Eppley RW (1981) Autotrophic production of particulate matter. In: Longhurst AR (ed) Analysis of marine ecosystems. Academic Press, London, p 342-361

Eppley RW, Peterson BJ (1979) Particulate organic matter flux and planktonic new production in the deep ocean. Nature 282:677-680

Fasham MJR (2003) Ocean biogeochemistry: the role of the ocean carbon cycle in global change. Springer-Verlag, Berlin

Fuhrman J (2003) Genome sequences from the sea. Nature 424:1001-1002

Geddes D, Armsworthy S, Dennis P, St-Laurent B (eds) (2003) Bedford Institute of Oceanography 2002 in review. $40^{\text {th }}$ anniversary edition. DFO \& NRCan, Dartmouth

Hachey HB (1961) Oceanography and Canadian Atlantic waters. Fish Res Bd Can Bull 134

Halliday RG, Fanning LP (2006) A history of marine fisheries science in Atlantic Canada and its role in the management of fisheries. Proc NS Inst Sci 43:159183

Hargrave BT (1985) Particle sedimentation in the ocean. Ecol Model 30:229-246

Hargrave, BT (ed) (2005) Environmental effects of marine finfish aquaculture. In: Hutzinger $\mathrm{O}$ (ed-in-chief) The handbook of environmental chemistry, Vol 5M. Water pollution. Springer-Verlag, Berlin/Heidelberg

Harrison PJ, Parsons TR (2001) Fisheries oceanography: an integrative approach to fisheries ecology and management. Blackwell Science Ltd, Oxford

Head EJH, Brickman D, Harris L (2005) An exceptional haddock year-class and unusual environmental conditions on the Scotian Shelf in 1999. J Plankton Res 27:597-602

Herman AW (1988) Simultaneous measurement of zooplankton and light attenuance with a new optical plankton counter. Cont Shelf Res 8:205-221

IGBP (International Geosphere-Biosphere Programme) (2003) Surface Ocean - Lower Atmosphere Study, Science Plan and Implementation Strategy. IGBP Report 50

Khelifa A, Pahlow M, Vezina A, Lee K, Hannah C (2003) Numerical investigation of impact of nutrient inputs from produced water on the marine planktonic community. $26^{\text {th }}$ Proceedings of Arctic and Marine Oil Spill Program (AMOP), Victoria, BC, p 323-333

Li WKW (2002) Macroecological patterns of phytoplankton in the northwestern North Atlantic Ocean. Nature 419:154-157 
Li WKW, Subba Rao DV, Harrison WG, Smith JC, Cullen JJ, Irwin B, Platt T (1983) Autotrophic picoplankton in the tropical ocean. Science 219:292-295

Li WKW, Head EJH, Harrison WG (2004) Macroecological limits of heterotrophic bacterial abundance in the Ocean. Deep-Sea Res I 51:1529-1540

Longhurst AR (2001) Ecological geography of the sea. Academic Press, London

Longhurst AR, Sathyendranath S, Platt T, Caverhill C (1995) An estimate of global primary production in the ocean from satellite radiometer data. J Plankt Res 17:1245-1271

Martin JH, Coale KH, Johnson KS, Fitzwater SE and 40 others (1994) Testing the iron hypothesis in the ecosystems of the equatorial Pacific Ocean. Nature 371:123-129

Mills EL (1989) Biological oceanography: an early history, 1870-1960. Cornell University Press, Ithaca

Murray J, Hjort J (1912) The depths of the ocean. Macmillan and Company, London

Pahlow M, Vézina A (2003)Adaptive model of DOM dynamics in the surface ocean. J Mar Res 61:127-146

Parsons TR (1975) Biological oceanography in Canada: a perspective and review. J Fish Res Bd Can 32:2231-2283

Parsons TR (2002) Future needs for biological oceanographic studies in the Pacific Ocean. In: Perry RI, Livingston P, Bychkov AS (eds) PICES science: the first ten years and a look to the furure. PICES Scientific Report No 22, p 35-42

Parsons TR (2003) Macroecological studies of the ocean. Oceanography in Japan 12:370-374

Parsons TR (2004) The sea's enthrall. Memoirs of an oceanographer. Ecce Nova Editions, Victoria, BC

Parsons TR, Lalli CM (1988) Comparative oceanic ecology of the plankton communities of the subarctic Atlantic and Pacific oceans. Oceanogr Mar Biol Ann Rev 26:317-359

Parsons TR, Takahashi M, Hargrave B (1984) Biological oceanographic processes, $3^{\text {rd }}$ edn. Pergamon Press, Oxford

Pauly D, Christensen V, Walters C (2000) Ecopath, ecosim, and ecospace as tools for evaluating ecosystem impact of fisheries. ICES J Mar Sci 57:697-706

Platt T, Sathyendranath S, Longhurst A (1995) Remote sensing of primary production in the ocean: promise and fulfillment. Phil Trans R Soc Lond B 348:191202

Platt T, Fuentes-Yaco C, Frank KT (2003) Spring algal bloom and larval fish survival. Nature 423:398-399

Reeve MR, Grice GD, Harris RP (1982) The CEPEX approach and its implications for future studies in plankton ecology. In: Grice GD, Reeve MR (eds) Marine mesocosms: biological and chemical research in experimental ecosystems. Springer-Verlag, New York, p 389-398

Rivkin RB, Legendre L (2001) Biogenic carbon cycling in the upper ocean: effects of microbial respiration. Science 291:2398-2400

Rivkin RB, Tian, R, Anderson MR, Payne JF, Deibel D (2000) Ecosystem level effects of offshore platform discharges - identification, assessment and modelling. In: Penney KC, Coady KA, Murdoch MH, Perker WR, Niimi AJ (eds) Proceedings of the $27^{\text {th }}$ annual aquatic toxicity workshop, October 1-4, 2000, St John's, Newfoundland. Can Tech Rep Fish Aquat Sci 2331, p 3-12 
Sinclair M, O'Boyle R, Burke L, D'Entrement S (1999) Incorporating ecosystem objectives within fisheries management plans in the Maritimes region of Atlantic Canada. ICES CM 1999/Z:03

Stewart JE (1991) A brief review of the International Council for the Exploration of the Sea (ICES) on the occasion of the formation of the North Pacific Marine Science Organization. Can J Fish Aquat Sci 48:2543-2550

Strickland JDH, Parsons TR (1972) A practical handbook of sea-water analysis, $2^{\text {nd }}$ edn. Fish Res Bd Can Bull 167

Therriault J-C, Petrie B, Pepin P, Gagnon J and 8 others (1998) Proposal for a northwest Atlantic zonal monitoring program. Can Tech Rep Hydrog Ocean Sci No 194

Turrell WR (2005) The policy basis of the "Ecosystem Approach" to fisheries management. EuroGOOS Publ No 21, SMHI, Oslo

Venter JC, Remington K, Heidelberg JF, Halpern AL and 19 others (2004) Environmental genome shotgun sequencing of the Sargasso Sea. Science 304:66-74

Vézina, AF, Berreville F, Loza S (2004) Inverse reconstructions of ecosystem flows in investigating regime shifts: impact of the choice of objective function. Prog Oceanogr 60:321-341

Wiebe PH, Beardsley RC, Bucklin AC, Mountain DG (eds) (2001) Coupled biological and physical studies of plankton populations on Georges Bank and related North Atlantic regions. Deep-Sea Res II 48(1-3):1-684

\section{GLOSSARY AND WEB-LINKS}

ArcticNet - ArcticNet, Network of Centres of Excellence of Canada (http://www. arcticnet-ulaval.ca)

AZMP - Atlantic Zone Monitoring Program

BIO - Bedford Institute of Oceanography

BODC - British Oceanographic Data Centre (http://www.bodc.ac.uk/)

CASES - Canadian Arctic Shelf Exchange Study (http://www.cases.quebec-ocean. ulaval.ca/index.html)

CCGS Amundsen - Canadian Research Icebreaker (http://www.amundsen.quebec-ocean.ulaval.ca)

CMB - Centre for Marine Biodiversity (http://www.marinebiodiversity.ca/en/corridor. html)

COML - Census of Marine Life (http://www.coreocean.org/Dev2Go.web?Anchor= coml_home_page\&rnd=15141)

DFO - Dēpartment of Fisheries and Oceans

EC - Environment Canada

EBFM - Ecosystem-based fisheries management

ECOPATH - (http://www.ecopath.org/)

ESSAS - Ecosystem Studies of Sub-Arctic Seas - (http://www.pml.ac.uk/globec/ structure/regional/essas/essas.htm)

GFC - Gulf Fisheries Centre

GLOBEC - Global Ocean Ecosystem Dynamics (http://www.pml.ac.uk/globec/main. htm)

GOOS - Global Ocean Observing System (http://ioc.unesco.org/goos/)

ICES - International Council for the Exploration of the Sea 
IDOE - International Decade of Ocean Exploration

IGBP/SCOR - International Geosphere-Biosphere Programme / Scientific Committee on Oceanic Research. Draft framework for future research on biological and chemical aspects of global change in the ocean (http://www.igbp.kva. se/obe/FW-Final-2002.pdf)

IMBER - Integrated Marine Biogeochemistry and Ecosystem Research. Draft Science Plan and Implementation Strategy (http://www.igbp.kva.se/obe/IMBERSP-IS-15Jan04.pdf)

IOS - Institute of Ocean Sciences

IPCC - Intergovernmental Panel on Climate Change (http://www.ipcc.ch)

IPY - International Polar Year Canada (http:/www.ipy-api.ca)

JGOFS - Joint Global Ocean Flux Study (http://www.uib.no/jgofs/jgofs.html)

Kyoto Protocol - (http://unfccc.int/resource/docs/convkp/kpeng.pdf)

Lunenburg Bay Project - Interdisciplinary Marine Environmental Prediction in the Atlantic Coastal Region (www.cmep.ca/bay)

MEDS - Marine Environmental Data Service (http://www.meds-sdmm.dfo-mpo. gc.ca/meds/Home_e.htm)

MLI - Maurice-Lamontagne Institute

MPA - Marine Protected Area

NEPTUNE - North-east Pacific Time-series Undersea Networked Experiments (http://www.neptunecanada.ca)

NODC - National Oceanographic Data Center (http://www.nodc.noaa.gov/)

NOW - International North Water Polynya Study (http://www.fsg.ulaval.ca/giroq/ now/wel.htm)

NRCan - Natural Resources Canada

NSF - National Science Foundation

NWAFC - Northwest Atlantic Fisheries Centre

OEUVRE - Ocean Ecology: Understanding and Vision for Research (http://www. ofps.ucar.edu/joss_psg/project/oce_workshop/oeuvre/report/Entire.pdf)

OWS - Ocean weather station

PBS - Pacific Biological Station

POGO - Partnership for Observation of the Global Oceans. Biological observations of the global ocean: requirements and how to meet them (http://ocean-partners. org/documents/Dartington_Report.pdf)

Polynya - An area of open water in high latitude oceans surrounded by sea ice, often referred to as "north water"

SABS - St Andrew's Biological Station

SEAMAP - Seabed Resource Mapping Program (http://seamap.bio.ns.ca/)

SOLAS - Surface Ocean - Lower Atmosphere Study (http://www.uea.ac.uk/env/ solas/)

UBC - University of British Columbia 